UDC 327::911.3(262)

DOI: https://doi.org/10.18485/iipe_ria.2020.71.1179.3

Biblid 0543-3657, 71 (2020)

Vol. LXXI, No. 1179, pp. 54-76

review paper

\title{
POLITICAL AND STRATEGIC CHANGES IN THE MEDITERRANEAN
}

\author{
Slobodan M. RADOJEVIĆ 1
}

\begin{abstract}
The paper elaborates on the geostrategic significance of the Mediterranean and the Mediterranean Sea in the past, as a precondition for consideration of current and future events in this macro-region. The author firstly considers the manifestation of the power, influence and interests of the great powers in the Mediterranean through a historical and spatial perspective. The paper analyses political and economic changes in the Mediterranean through the theoretical and practical approach of great powers ' navies engagement. The author points out that the geopolitical and geostrategic importance of the Mediterranean will further increase in the future, as a result of constant regional and global aspirations to increase the political and economic dynamics of this region. The growing competition between the United States and China will have a direct impact on the Mediterranean. The author concludes that the Mediterranean will remain a „testing polygon“ for the United States, China and Russia, and a region in which political and economic processes and strategic changes in the world could be witnessed most obviously.
\end{abstract}

Keywords: Mediterranean, Mediterranean Sea, strategic changes, political and economic processes, United States, China, Russia.

\section{THE MEDITERRANEAN THROUGH HISTORY}

The great French historian Fernand Braudel (1902-1985), who studied the history of the Mediterranean, claimed that the Mediterranean Sea was part of the largest landmass in the world. He stated in a brilliant essayist style that the Mediterranean was a kind of planet, where goods and people have been moving since ancient times. Braudel also argued that it was on these three connected continents that people found a great stage for their history and that the crucial events took place there. (Brodel 2007, 33-34). For several centuries the

\footnotetext{
${ }^{1}$ Slobodan Radojević, Ph.D., Lecturer, Military academy, University of Defence, Belgrade. E-mail: slobodan.radojevic@va.mod.gov.rs
} 
Mediterranean Sea has been the most important geopolitical and geostrategic center of the world (Diaconu 2008, 43). Namely, for thousands of years, the Mediterranean was a strategic region. Empires rose and fell in the Mediterranean (Greenwood 1993, 2). Also, the Mediterranean Sea, "plays a greater part in the history of the world, both in a commercial and a military point of view, than any other sheet of water of the same size" (Mahan 1890, 33). The Mediterranean Sea is rightly considered the cradle of the power of large fleets (Gorškov 1979, 113). The first large fleets were built in the Mediterranean, i.e., the navies that were the guarantor of the power of these states. In fact, naval power was a significant component in the growth and maintenance of the earliest civilizations of the Mediterranean.

The past of the Mediterranean offers ample opportunities to study the conquest, the movement of peoples, the emergence and disappearance of empires and colonial empires, the many circumstances and personalities of which the destinies of states and peoples depended. (Živojinović 1980, 9). The history of the Mediterranean abounds in turbulent events where politics and wars are constantly intertwined, and economic and religious conflicts are constantly looming behind them. The struggle for domination in the Mediterranean testifies to the constant efforts of the early civilizations, and later of the great powers, to reach its shores, strengthen, expand and suppress other nations and states on them.

The position of the Mediterranean has geopolitical and geostrategic influence, which throughout history to these days have manifested themselves directly and complexly on the surrounding countries, as well as on the entire world. After the Second World War, the political picture of the Mediterranean changed drastically. Colonial powers - Great Britain, France and Italy, are losing their possessions in the Mediterranean regions. Weakened Great Britain could no longer protect its geostrategic interests and positions, so its place was taken by the United States, which established naval and air bases in the Mediterranean and formed a strong naval strike force - the Sixth Fleet.

Since major geographical discoveries, the central role of the Mediterranean has gradually decreased. However, in modern times, by the XX century, the Mediterranean did not lose its relevance, and in the XXI century, it became the main arena of competition between the great powers and economic and cultural exchange. Today, the interests of the great powers such as the United States, Russia and China, as well as other regional powers, are intertwined in the Mediterranean. In addition to the old actors, China is gradually becoming stronger in the Mediterranean economically, diplomatically, and eventually geostrategically. (Mordechai 2018, 54-69). Namely, in the Mediterranean today, as it was in the past, it is most obvious that the navies serve as a guarantor of securing maritime trade in the way that theoretically explained Alfred Thayer Mahan (1840-1914) 
and Julian Corbett (1854-1922) (Black 2006; Parker 2003; Adamczyk, Rutkowska 2018, 1-16; Luttwak 1974; Naj 2012; Горшков 1979).

Through the theoretical framework of the application of naval suasion and maritime diplomacy according to Edward Luttwak, Joseph Nye and Sergey Gorshkov, we can also observe the actions of the navies of the United States, Russia, and China in the Mediterranean (Rowlands 2012, 93-109; Widén 2011, 715-733; Li 2009, 144-169; Cheng 2011, 1-12; Chang 2018, 148-156).

On the other hand, the Mediterranean basin is a region of great challenges due to the pressures of globalization, demographic growth in all non-European countries of the region, and potential unrest (Kissinger 2002, 53, 54). Today, the Mediterranean region abounds in local disputes that are of territorial, national, or religious origin. In general, the Mediterranean is "geostrategically and politically an extremely sensitive area and a potential crisis hotspot due to different political, military-political orientations, levels of economic development, social turmoil, wars, recent civil wars and revolutions in Arab countries." (Radojević 2017a, 55).

In this paper, the focus is on political, economic and strategic changes and processes that are a consequence of the actions of the great powers. The influence of the European Union as an important actor in the Mediterranean is largely limited due to differences between member states and their different historical, political, cultural, social and economic presence, and influence in the Mediterranean states. The European Union has several regional concepts and strategies for the Mediterranean, such as the Euro-Mediterranean Partnership and the Union for the Mediterranean, as well as the European Neighbourhood Policy. Also, the European Union is present with its naval forces in several naval security operations. For purposes of this study, consideration of the EU as a geostrategic and geopolitical actor in the Mediterranean will be indirectly analyzed. (For further reading see: Pierini, 2017; Frankenthal 2019; Khader \& AmirahFernández, 2020).

Today, the Mediterranean Sea is an unavoidable and most dangerous migrant route caused by crises and wars in the coastal states and hinterland of the Mediterranean. (International Organization for Migration [IOM] 2018; [IOM] 2017; Steinhilper, Gruijters 2018, 515-533). In fact, in recent years, the Mediterranean Sea has become a "maritime cemetery" in which a large number of migrants and refugees have died. (Tazzioli 2015, 2-6). The control of the migrant crisis and the rescue of migrants in the Mediterranean Sea includes the naval forces of the European Mediterranean countries, but also the multinational naval forces of the European Union. 


\section{GEOSTRATEGIC SIGNIFICANCE OF THE MEDITERRANEAN SEA}

The Mediterranean consists of a series of compact, mountainous peninsulas, interrupted by vital plains: the Iberian, Apennine and Balkan peninsulas, Asia Minor and North Africa. In fact, the Mediterranean Sea is much more than a single body of water, it is a "complex of seas". (Braudel, 1972, 23-27).

According to some authors, the Mediterranean, in addition to the area of all countries that reach the shores of the Mediterranean Sea, includes the entire area that gravitates economically towards the countries on the shores of this sea. (Martinez, Murdock, and Schaeffer 2013, 8-10). Although they do not have direct access to the sea, UNESCO, in addition to Portugal, Jordan, Serbia and North Macedonia, has included Andorra, San Marino and the Vatican in the Mediterranean countries because they are located in the region, gravitate to the area, or are related to the Mediterranean culture, history and tradition. (Adamo and Garonna 2009, 73-84).

The Mediterranean encompasses the Mediterranean Sea, which is a vast intercontinental sea of the Atlantic Ocean, located between Europe, Asia and Africa, and which by its position does not divide, but connects these continents. It represents the central part of the Mediterranean towards which a large part of the mainland of the three continents of "the Old World" gravitates (Marjanović 1983, 213). The Mediterranean Sea is connected to the Atlantic Ocean by the Strait of Gibraltar, and the Suez Canal to the Red Sea and the Indian Ocean. As a border of three continents and a crossroads of important sea and air routes, it is an extremely important economic, traffic, and strategically unique region. It is the most important and sensitive part of the Atlantic-Mediterranean-Asian world waterway. It has a very important military-geographical position between the Atlantic and Indian waters, between the mainland of Europe, Asia and Africa, as well as between the industrialized countries of Europe, without key raw materials, and the underdeveloped and rich countries of the Middle East and North Africa.

The Apennine Peninsula, Sicily and the submarine threshold between Tunisia and Sicily divide the Mediterranean Sea into two basins, the Western and Eastern Mediterranean. The economic-geographical and strategic characteristics of the eastern and western parts of the Mediterranean differ significantly. Unlike the Western Mediterranean, the eastern part of the Mediterranean is a zone of more tensions. In the eastern part of the Mediterranean, tensions between Greece and Turkey occasionally occur, often ending in the deployment of large naval and military forces. Namely, in this part, Greece and Turkey are in conflict over Cyprus. There are also the leading Arab countries and Israel as an "outspoken ally of the West". The Arab-Israeli and Israeli-Palestinian conflict and the civil 
war in Syria are burdening this region. There are oil pipelines in the Eastern Mediterranean, significant natural gas deposits have been discovered, and there is also one of the most important artificial sea waterways - the Suez Canal. By interpreting the geopolitical significance of the Mediterranean, it becomes clear why for centuries the Mediterranean Sea has been a space of strategic importance in the conflict of great powers for domination and influence in Europe, Asia, and Africa. Namely, the Mediterranean with the Middle East is very rich in raw materials, the most important of which is oil and gas, which will be discussed in more detail below.

Also, dominance over the Mediterranean part of the African continent and the Middle East enables the control of the sea and air routes to the Atlantic, Western and Southern Europe, South Asia, and the Indian Ocean. Therefore, the great powers have continuously throughout history sought to achieve their supremacy on this sea, and to achieve such a goal they have used naval and air forces to secure supremacy at sea and in the air. The struggle for domination in the Mediterranean testifies to the constant efforts of the great powers to reach its shores, strengthen, expand, and suppress others on them. Their rivalry and attempts to oust each other lead to occasional wars in the Mediterranean and the coastal states. (Živojinović 1980, 9).

The global role of the Mediterranean Sea began to grow again after the Second World War. Such a development of the situation was caused, above all, by the very nature of the Cold War. Let us recall, one of the earliest elements of what became a containment policy was the Truman Doctrine, according to which the United States provided direct assistance (mostly financial and economic, but also military) and strategic protection to Greece and Turkey in order to help these Mediterranean countries to face the Soviet threat (Diaconu 2008, 45). With geostrategic pressures on Greece and Turkey, as well as the straits of the Bosphorus and Dardanelles, Soviet policy was directed towards the development of diplomatic relations with Iran and certain Arab states. In this way, the USSR penetrated deep into the areas of the special strategic interest of Great Britain and later the United States (Cvrtila 2004, 19-20). The activities of the USSR in the eastern part of the Mediterranean were connected with securing the Black Sea basin, which the Soviet Navy considered as its "own sea".

Later, the strategic rivalry between the two superpowers intensified rapidly throughout the Mediterranean. The Soviet Union perceived the Mediterranean as a region vital for the success of possible "major strategic offensive operations along several major directions (and in several theatres of operations)" (Diaconu $2008,45)$. In the late 1960s, the Mediterranean became a region of almost open conflict between the two superpowers. Also, the USSR provided great assistance and sent military advisers to Syria and Egypt, while the United States strongly supported Israel, and later Egypt. (Diaconu 2008, 45). Libya developed 
cooperation with the USSR after coming to power of Muammar Gaddafi on 1 September 1969.

Even in modern conditions, the Mediterranean Sea is gaining more and more importance. In fact, the Mediterranean Sea "lies at the center of a security nexus whose geopolitical importance has increased since the end of the Cold War". (Germond and Grove 2010,1). Therefore, it is not surprising that the first joint post-Cold War NATO activities were related to the Mediterranean area. (Čehulić Vukadinović 2010, 237).

The geostrategic importance of the Atlantic Ocean tends to decrease since Euro-Atlantic maritime communications are no longer endangered. In contrast, from the point of view of Western European countries, the Mediterranean Sea, surrounded by crises and instabilities that affect maritime communications, is gaining increasing geostrategic significance.

The geostrategic position of the Mediterranean is determined and encompassed by geopolitical relations and the grouping of strategic elements. The Mediterranean as a sea area has a special place within the naval and air strategy, because using the freedom of navigation, strong naval forces with a significant air component, as well as strategic nuclear submarines can deploy in it. The Mediterranean Sea and its international legal regime allow the naval presence of non-Mediterranean countries. With such a position, it increases the possibility of efficient application of the most modern combat systems possessed by the great powers` navies. (Marjanović 1983, 212). The fragmented waters of the Mediterranean Sea can also have their tactical, operational and strategic application. Namely, the long sea coast, numerous bays and coves provide excellent conditions for the deployment and replenishment of warships. There are numerous islands with ports in the Mediterranean Sea, of which Cyprus, Crete and Malta are the most important in the military sense. Even in modern war conditions, these islands are of great importance and serve as a support for the actions of naval forces and systems and as ,unsinkable aircraft carriers“, i.e., they have airports and bases (214). The depth of the Mediterranean Sea and the relief of the bottom provide optimal conditions for the use of submarines. In addition, air supremacy is key to conducting land and naval operations in the Mediterranean. Achieving air supremacy in this sea is partly facilitated by its relatively small width, the availability of a large number of air bases on land, and especially on the islands, as well as the presence of aircraft carriers. The eastern and western basins are important for the actions of larger naval forces. The western basin is important because of the Atlantic - the Mediterranean Sea and Europe - Northwest Africa connection and because of the increase in the depth of NATO's special battlefield in Europe and the Mediterranean. These benefits were especially used during the intervention in Libya in 2011 (Radojević 2017b). The eastern basin of the Mediterranean Sea has an extremely important military- 
geographical position in relation to the wider area between the three continents, due to strategic raw materials in the Middle East, connection with the Indian Ocean, the Suez Canal and the Bosphorus and Dardanelles straits, as well as political, economic and military influences and interventions (Marjanović 1983, 214). During the war in Syria, the NATO naval and air forces (primarily the United States) and the Russian naval and air forces operated from the eastern basin of the Mediterranean Sea.

In fact, the Mediterranean has an ideal position and can be used as an operational zone in relation to continental Europe, internal Africa, the Middle East, the Indian Ocean and the Atlantic - practically, in relation to the world's crisis hotspots. The position of the Mediterranean in Rimland emphasizes its exceptional geopolitical and geostrategic significance. The Mediterranean is a part of Rimland where geopolitically very important sea straits and corridors are located: Gibraltar, the Bosphorus and Dardanelles, the Suez Canal and the most important internal sea corridor on the earth's surface, the corridor of the Mediterranean and the Black Sea about 6,000 kilometers long. (Pavić 1971a, 86). The general features of the Mediterranean Sea in Rimland are "dictated" by the interests and the presence of the great powers as well as the ongoing processes of the militarization of the region (Pavić 1971b, 399; Celac et all. 2019).

As a geographical area, it is not just a physical link in terms of traffic connections between the US military allies in Eurasia. The Mediterranean is more than that, precisely because of its geographical position. It is the backbone of the land, sea and air routes that in peace, but also wars, forms lines of connection with the allies along the southern edge of Eurasia. Thus, the Mediterranean, with its sea and air routes, has a special place in the geostrategic picture of the world in case the classic and limited nuclear war. (Božić 1974, 188-191).

In fact, as Vukovic concludes, the Mediterranean is "currently the most important global geostrategic hub of cross-cutting interests of major and regional powers." (Vuković 2017, 269). Also, the military aspects of the geostrategic position are very important when considering political and economic aspects. Namely, the geostrategic significance of the Mediterranean is closely connected with the geoeconomic significance, first of all, its traffic and energy dimension.

\section{GEOECONOMIC SIGNIFICANCE OF THE MEDITERRANEAN}

Strategic key world waterways pass through the Mediterranean Sea, with around 7,000 merchant vessels sailing them daily. (Mays 2013,34). Approximately $80 \%$ of global trade by volume and over $70 \%$ of global trade by value is transported by sea ([UNCTAD] 2018). Also, the Mediterranean Sea is an area of transit and exchange that accounts for about $30 \%$ of the world's maritime trade, 
as well as $25 \%$ of the world's maritime oil transport. Also, most of the European Union's maritime trade with Asia and the Middle East takes place via the Mediterranean Sea lines of communications. The Mediterranean is also part of a key energy and communication infrastructure. It currently includes four gas pipelines connecting Europe and North Africa, a large number of liquefied petroleum gas terminals, as well as important submarine communication cables. The discovery of gas in the Eastern Mediterranean, as well as the exploitation of existing reserves in the Southern and Southeastern Mediterranean, suggests that this region will remain an important supplier of energy to Europe in the foreseeable future. (Behr et al. 2013, 25).

Since as much as $65 \%$ of European oil and natural gas imports pass through the Mediterranean, the energy security of this region is important for NATO. (Weissenbacher, 2012, 458) A safe and stable environment in this region is not only important for Western importing countries, but also for energy producers in the region, as well as for all countries involved in oil and gas transit. Therefore, NATO influences energy security through forms of partnership and cooperation (Partnership for Peace, Mediterranean Dialogue, Istanbul Cooperation Initiative and NATO Middle East Initiative) with countries rich in oil and gas, the wider Mediterranean region, the Middle East and Central Asia. (Čehulić Vukadinović 2010, 257). Oil, as a strategic raw material, is the most important of all factors that determine the geopolitical and geostrategic position of the wider Mediterranean region, with complex and global consequences for the economic, political, and military structure in modern international relations. In the Mediterranean, due to the complex political and economic situation, which has a global scale, the oil wealth of the Mediterranean countries has influenced the entire region to gain even greater geopolitical and geostrategic significance. Oil wealth has an irreplaceable positive impact on the development, wealth and power of states and has changed the entire life mile of Arab states, as well as the entire life, consciousness, and even the history of those countries. However, in addition to the stated positive impact, oil also had a negative impact on the Mediterranean countries. They have very often been the target of pressure, and especially since the discovery of new sites and larger reserves. For the NATO countries, the Mediterranean is of vital importance, considering the fact that the countries of Western Europe do not have a sufficient amount of oil, but in the largest percentage, they supply this raw material from the Arab countries through the Mediterranean.

Nebojsa Vukovic points out that having in mind all the facts, both in the field of transport and energy, it is not an exaggeration to say that the Mediterranean with areas that gravitate to it geographically (primarily the Middle East), is the most important part of the 'global economic flow' and geoeconomic hub of key importance in the world (Vuković 2017, 275). 
The dependence of the United States and NATO members on the transportation of Middle Eastern oil transported by sea through the Mediterranean Sea gives it great strategic importance. In addition, North Africa and the Middle East have almost 5\% of the world's proven oil reserves and about $5 \%$ of the confirmed gas reserves. (Hafner, Tagliapietra and El Elandaloussi 2012, ii). The North African countries of the Mediterranean, primarily Libya, Algeria and Egypt, are rich in oil and gas. An additional geostrategic importance of these sites is that they are located outside the Middle East conflict zone. In these countries, there are ports for loading oil and from these countries, gas pipelines run to European NATO member states. Namely, coastal refineries and oil pipelines in the Mediterranean are geostrategically very sensitive locations.

Today, the geostrategic and geoeconomic role of the Mediterranean Sea for the United States, the EU and NATO countries is growing even more because, above all, their long-term stability and prosperity are connected with the stability in the Mediterranean region, i.e., in the Middle East and North Africa. Besides, in the last decade, the geostrategic and geoeconomic role of the Mediterranean has increased for China and Russia. Therefore, the geostrategic and geoeconomic role of the Mediterranean could be studied in the framework of strategic and security studies. (see Radojević 2018, 77-94).

\section{INTERESTS OF THE GREAT POWERS AND STRATEGIC CHANGE IN THE MEDITERRANEAN}

The interests of the great powers in the Mediterranean date far back in time and represent the initiators of great strategic changes in this macro-region. The Mediterranean engagement of the United States is old and multiple. Ian O. Lesser states that for over 200 years the United States has been an economic, diplomatic, and security actor in this region. Lesser also claims that the recent security situation on Europe's southern periphery, and in Europe itself, confirms the central place of the Mediterranean in transatlantic issues. (Lesser 2015, 1). During the two world wars, as well as the Cold War, the transatlantic engagement of the United States has always been significant in the Mediterranean, even if this aspect of US strategy was often subordinated to demands in other parts of the European continent. (Lesser 2015, 1).

Immediately after the Second World War, the United States recognized the importance of the Mediterranean region for projecting power and began to form a fleet in the Mediterranean. In the coming years, the US Mediterranean Fleet will be formed, which will strengthen, and its task will be very important in contemporary circumstances. That is why it can be rightly said that the initial confrontation between the United States and the USSR before the formation of NATO and the beginning of the Cold War was in the Mediterranean. Also, one 
of the most famous programs of US foreign policy, the Marshall Plan, started in the Mediterranean region (Dillery 2006, 9).

After the formation of NATO, the US Mediterranean (Sixth) Fleet will be given clear tasks and roles, the backbone of which is the projection of US power and keeping Europe and the Mediterranean under constant surveillance. The US presence in that region of the Mediterranean embodied in the Sixth Fleet is perceived as vital, not only for US and NATO interests but also for US nonNATO interests in the Mediterranean and the Middle East. (Greenwood 1993, 7; Calleya 2019). On the other hand, impoverished and war-exhausted European states could not form a fleet of such a force in the Mediterranean. In fact, the Cold War policy and the aggravation of the situation in Europe were an additional justification for the existence of a strong American fleet in the Mediterranean.

It is rightly considered that the Cold War, before it came to light in its original form, already had a small history that preceded it in the Mediterranean and the Middle East, then in Europe, and only later in Asia. Due to its military superiority in the air and at sea from 1945 to 1947, the United States forced, if not coerced, the USSR to political retreat in the Mediterranean in a broader sense. (Božić 1974, 109). Hence the special geostrategic significance of the Mediterranean for the global strategy of the United States (1974, 188-189).

However, the United States usually does not perceive the Mediterranean as a coherent strategic space and area of interest for the United States per se. In the political context, the traditional approach of the United States was to divide the Mediterranean along geopolitical lines into Europe, including Turkey on the one hand, and the Middle East and North Africa on the other (Lesser 2015, 5).

The Mediterranean for the United States is an indispensable area for the operational presence and use of strong and diverse naval and air forces and missile carriers for strategic and operational purposes, in order to protect interests; an area for the use of naval forces (strike and combat groups for different purposes) in different types of operations in military interventions; an area for maneuvering and regrouping naval forces (sending parts or entire formations of the strike or combat groups) from the Atlantic, the Indian Ocean to the Mediterranean or vice versa, as well as an area where the most important interests are the provision of unhindered naval communications for economic and military reasons. The United States mainly views the Mediterranean in a broader context. In fact, for the United States, its main importance lies in the security of their access to oil reserves in the Middle East and the Persian Gulf. For the United States, the Mediterranean is the basis for the projection of power in the Persian Gulf. This was demonstrated during the Gulf War. Some $90 \%$ of the troops and military materiel sent to the Gulf passed through or above the Mediterranean. (Lesser 1998, 220). 
For the United States, a naval presence in the Mediterranean and strong military positions in the coastal seas are a condition for a successful strategy and security in Europe. In this region, the policy of threats, pressure and force materialized through the forces of the US Sixth Fleet, and later the Standing NATO Naval Force. (Zoppo 1982; Vukadinović 1986). The United States and NATO intervened with naval and air forces during the war in the former SFRY, FRY and Libya. Based on research and analyzed data from NATO naval and air operations, and especially operations in which force was used, their impact on political changes in the countries against which they were conducted was shown. (see in Radojević 2017b). Also, the United States and its allies have repeatedly intervened with naval and air forces during the war in Syria from the Eastern Mediterranean to target government forces. (Blomdahl 2019, 536-555). On the other hand, Russia has repeatedly targeted the targets of the "Islamic State" from warships and submarines from the Mediterranean Sea, and on two occasions from warships from the Caspian Sea.

Thus, during the Ukrainian crisis, NATO increased its naval presence in the Eastern Mediterranean. Therefore, it is not surprising that the Eastern Mediterranean is considered the Achilles' heel of the post-Cold War era of the Western world. (Litsas 2018, 169-190). The Eastern Mediterranean is a "geostrategic seam" between Europe and the Middle East. The region has been a "strategic anchor" for the United States for over seventy years. It serves in strengthening Europe and limiting instability in the Middle East. Today, the United States and its allies are struggling to keep the Eastern Mediterranean "transatlantically" anchored, while dramatically acknowledging the region's new economic, political, and security reality. As Syria enters its seventh year of conflict, Russia and Iran deepen their military "footprint" in the region, and Turkey, as a member of NATO, radically changes its domestic and foreign policies, the strategic importance of the Eastern Mediterranean for the United States is growing. (Foggo 2019).

Modern Russia, like the Soviet Union, pursued a policy of slow but stable strategic and economic penetration into the countries of the Eastern Mediterranean, especially Turkey, Greece, and Cyprus. Russia's main goal is to ensure the widest possible influence in the region, which is rapidly gaining in importance because of its energy reserves and key strategic position. (Stergiou 2012). Throughout its history, Russia has strived to achieve a more significant presence in the Mediterranean, especially by deploying naval forces. The deployment of Russia's naval forces in the Mediterranean was accompanied by Russia's new Naval Doctrine, published in July 2015. (Морская Аоктрина Российской Федерации 2015). This doctrine indicated Russia's intentions to maintain a permanent naval presence in the Eastern Mediterranean in support of Russia's broader foreign and security goals. The doctrine also states a number 
of other goals, including the construction of a modern navy equipped with better new weapons systems. (Connolly 2017). Namely, Russia continues to modernize its armed forces, especially the Navy. In this way, Russia strives to apply the socalled showing the flag in the Mediterranean Sea, which is a demonstration of naval power (Thornton 2018, Thornton 2019). In fact, showing the flag is such an adopted and impressive maritime activity, that the phrase is a term to demonstrate the sea power of a country.

Russia has grown from a "green-water" navy to a "blue-water" navy in the past few years, clearly expressing its geopolitical interests in the Eastern Mediterranean. (Litsas 2016, 56-73). Some authors point out that "Russian hegemonic tendencies in the region" are reflected in the re-establishment of the Fifth Operational Squadron and the deployment of naval forces that took part in the Syrian civil war. Russia has also expanded its naval base in Tartus, Syria, and secured a long-term lease which will allow it to develop further this naval base. (Rubin and Eiran 2019, 989-990). During the war in Syria and the fight against the "Islamic State", Russia deployed strong naval forces in the Eastern Mediterranean. Namely, Russia conducted an operation in the Mediterranean Sea, engaging its naval forces (warships, submarines) and air forces for strikes on vital points, military and economic potentials of the "Islamic State". Russia also regularly holds naval exercises and increases the presence of naval forces in the Mediterranean. In August 2018, Russia conducted a large exercise in the Mediterranean, which included 25 warships from the fleets of the North, Baltic and Black Sea, together with strategic bombers. This naval presence in the region also enables Russia to develop closer cooperation with other global powers. In 2015 Russia also signed an agreement with Cyprus, which allows Russian navy ships to access Cypriot ports and may include other aspects of military cooperation. Moreover, Russia also signed an agreement with Spain, which is a member of the EU and NATO, which allows Russian ships access to its ports.

During the war in Syria, Russian warships patrolled near the coast in support of the Assad government. Russia also deployed its naval forces in the Mediterranean off the coast of Libya in support of Field Marshal Khalifa Haftar, the military leader of the eastern faction in Libya. (Srivastava 2016, 11; Zulfqar 2018, 121-147). In fact, Russia's entry into the region was facilitated by the withdrawal of the US Navy from the Mediterranean. In recent years, the Sixth Fleet, active in the region during the Cold War, has reduced its permanent presence to one command ship based in Italy and four destroyers equipped with AEGIS (multi-purpose anti-aircraft missile system) based at the Spanish naval base Rota. The withdrawal of the US from the region is not total. So, in April 2018, a US Navy Virginia class submarine participated in a cruise missile attack on targets in Syria. Shortly thereafter, the US deployed a carrier battle group in this region (Rubin and Eiran 2019, 989-990). In April 2019, two aircraft carriers 
sailed into the Mediterranean. On that occasion, from the command bridge of the aircraft carrier, the US Ambassador to Russia, Jon Huntsman, said that the US aircraft carriers in the Mediterranean were a signal that warned Russia: "When you have 200,000 tons of diplomacy that is cruising in the Mediterranean - this is what I call diplomacy. This is forward-operating diplomacy, nothing else needs to be said" (Pleitgen 2019; Рискин 2019).

Russia's goals in the Mediterranean are to ensure a sufficient maritime presence to control maritime traffic from the Black Sea region to the countries of the Mediterranean basin and to secure economic and political interests in the Mediterranean. The naval presence in the Mediterranean also gives Russia the opportunity to expand its presence and influence in strategically important regions of the Middle East and North Africa.

In addition to the Russians, Chinese warships appeared in the Mediterranean in the last decade. The Mediterranean is becoming a zone of growing interest for China, given that the wider Mediterranean region is not only an important source of energy but also a channel for the export of this rising power to Europe. China is present in the Indian Ocean and the Gulf of Aden, where its Navy is active in the fight against piracy. (Radojević 2012, 81-82). In doing so, it oversees this area by protecting its merchant maritime interests and maritime communications (Jérôme 2016; Rocha e Silva 2015, 708-732). China is also concerned about unrest and crises in the wider Middle East region and their possible consequences for China's internal stability. In military terms, this was reflected in the visits of the Chinese naval forces to European Mediterranean ports, joint exercises with Russia, Turkey, as well as the Chinese evacuation operation by sea during the Libyan war in 2011. (van der Putten 2016, 337-351). In May 2015, China and Russia conducted a significant ten-day naval exercise in the Eastern Mediterranean (Ekman 2018, 18).

Given the strategic position of the Mediterranean, China has strengthened its presence in the region by acquiring, modernizing, building, expanding and managing the most important Mediterranean ports and terminals in Algeria, Egypt, Greece, Israel and Turkey. (Chaziza 2018, 59) In fact, the Mediterranean is the ultimate western arm of the initiative for this growing power's Belt and Road Initiative (BRI). The initiative was personified and announced by President Xi Jinping (习近平) (see more in Jingping 2017, 543-566). As stated by Stepić (2019, 75-96) the Belt and Road Initiative ("One Belt, One Road"), i.e., "The New Silk Road", which consists of the land "Silk Road Economic Belt" and the "Maritime Silk Road for the 21st Century", represents the networking of Eurasia (and Africa) with geocommunication and geoeconomic routes that will ensure Chinese penetration and primacy. China's involvement in the Eastern Mediterranean is growing, marked by the provision of strongholds in Piraeus, as well as other steps of an economic and strategic nature in the region within the 
"Silk Road Strategy". (Skordeli 2015, 59-76; Casarini 2015). Due to contracts regarding the port Piraeus, Greece received the biggest amount of investment (Zakić and Radišić, 2019, 59). The port of Piraeus has a central strategic position in the Mediterranean and enables efficient further transport of goods by sea, road or rail. In fact, Piraeus is a geoeconomic hub between the East, the West and Africa (Müller-Markus 2016, 2). The presence of the Chinese naval forces in the Mediterranean increases the importance of a number of economic issues: the port of Piraeus has become an important starting point for Chinese products to Europe, and Chinese investments in transport infrastructure are beginning to affect the other logistics and port hubs in the area. Also, China and Italy signed an agreement of using the port of Trieste, which has huge strategic potential for the Chinese BRI, as it provides a link to the landlocked countries of Austria, Hungary, the Czechia, Slovakia, and Serbia.

These are large investments of Chinese corporations in transport and port facilities throughout the Eastern Mediterranean, such as the largest investments in the development of the Suez Canal, the lease of the Turkish port of Ambarli in Istanbul, the expansion of the southern Israeli port of Ashdod and the management of the northern Haifa port. Also, China has smaller investments in port facilities in Cyprus and Lebanon in the region (Rubin and Eiran 2019, 989990). Besides, China is expanding its financial investments in the Mediterranean hinterland by investing in railway and road infrastructure in Southeast Europe. China collaborates with North Macedonia in preparing a feasibility study for railway modernization. China signed a memorandum of understanding with Serbia and Hungary for the reconstruction of the Belgrade-Budapest railway link (Arase 2015, 1-11). All this will facilitate the transport of Chinese exports from Greek ports to European markets (Đorđević and Lađevac, 2016). In fact, Chinese goods reaching Piraeus could be transported by rail through North Macedonia and then Serbia to Hungary (Chaziza 2018, 59). In this way, China can use the Mediterranean's potential to become a major distribution hub for Chinese goods destined for the European Union, its largest trading partner. (Chaziza 2018, 55; Duchâtel and Duplaix 2018, 1-56). However, the Mediterranean region is extremely geopolitically unstable, and in the coming years will require this growing power to increase its efforts to protect its financial interests.

In addition, these investments combined with the increased presence of the Chinese naval forces could create more significant geopolitical and security effects. Actually, the Mediterranean countries could increasingly support Chinese positions in the region and beyond (Ekman 2018, 20). At the same time, it is important to note that China skillfully used the financial crisis in the smaller countries of the Eastern Mediterranean (Greece, Malta, and Cyprus) to position itself in strategically important areas. It is quite clear that due to the location of the region at the crossroads of Asia, Europe and Africa, control of the Eastern 
Mediterranean will continue to be vital to global geopolitics. Thus, the Eastern Mediterranean will continue to be a key to the global geopolitical balance of power, especially with China becoming a new player in the region. (Vamvakas 2014, 124-140).

\section{CONCLUSIONS}

Throughout history, the Mediterranean has been the cradle of the world's most important civilizations. For centuries, the Mediterranean Sea has been a strategically important area in which civilizations and the Mediterranean countries, and later the great powers, are fighting for influence in Europe, Africa and Asia. Therefore, this sea is considered the cradle of the power of large fleets. In the Mediterranean and the Mediterranean Sea, on this largest stage of world history, where the biggest and most significant events took place, the impermeability of the importance of space was once again confirmed.

Due to its geographical position, the Mediterranean is the backbone of the sea, air and land routes that connect Europe, Africa and Asia. Therefore, the Mediterranean is an extremely important economic, transport and strategically unique region. It is the most important and sensitive part of the AtlanticMediterranean-Asian world waterway. Also, the Mediterranean with the Middle East is very rich in energy, especially oil and gas. A large share of European oil and natural gas imports pass through the Mediterranean. The discovery and exploitation of gas in the Eastern Mediterranean suggest that this region will be a zone of more pronounced tensions between the great and regional powers in the foreseeable future.

The geopolitical and geostrategic importance of the Mediterranean will further increase in the future as a result of constant regional and global aspirations, which have the potential to significantly increase the political and economic dynamics in this region. The growing competition between the United States and China will have a direct impact on the Mediterranean. The global shift in the focus of power from the Atlantic to the Pacific has reduced the presence of the US naval forces in the region. On the other hand, in the Mediterranean, there is a competition between the US, China and Russia, as well as other regional powers. Especially since the Mediterranean Sea is one of the most important maritime communications in the world for global trade. In fact, due to the growing interconnectedness and the importance of the world maritime communications, the Mediterranean Sea is an unavoidable link of this system. In addition, geopolitical crises, conflicts and wars in other parts of the world, and especially in the wider Mediterranean region, are likely to increasingly affect the security of the Mediterranean. Besides, due to crises and wars in the 
Mediterranean region, the Mediterranean Sea has become an unavoidable and most dangerous migrant route.

The presence of naval forces of the great powers in the Mediterranean, as well as naval suasion and coercion by showing weapons in various exercises in the Mediterranean, confirm again the thesis about the use of warships to achieve political and economic goals. In the Mediterranean, it is the navies that enable the maintenance of political and military control over selected sea areas and the neighboring land, thus creating the conditions for the great powers to pursue their political and economic interests. In this region, the great powers are guided by the principle that the control over maritime communications, ports and the most important strongholds is of great importance for its overall development, security and prosperity. Actually, the Mediterranean is the extreme western arm of the Belt and Road Initiative for this growing power. Chinese financial investment in port development and other maritime infrastructure in the Mediterranean should be viewed in the context of broader Chinese infrastructure activities under the Belt and Road Initiative. In the last decade, China's naval activity in the Mediterranean Sea has been growing. China is gradually becoming stronger economically, politically, diplomatically, and eventually geostrategically in the Mediterranean. Securing investment in a region of extreme geopolitical instability will be a difficult test for China's foreign policy in the coming years. China does not have a comprehensive strategy regarding business in the Mediterranean region but instead prefers to cooperate bilaterally with each country. Also, Russia needs a showing the flag in the region to defend its economic and political interests, which it is very successfully realizing with the forces of the Navy. Access to the Mediterranean is very important for Russia and China, which are trying to gain the ability to manage economic, diplomatic and security flows through geopolitical and geoeconomic influence. Therefore, the United States will have to use all its resources - diplomatic, security, military and naval resources, as well as economic investments - to maintain the balance of power in a multipolar world whose creation is currently seen in the Mediterranean and the Middle East.

It is quite certain the Mediterranean will definitely remain a geopolitical, geoeconomic and geostrategic crossroads of three continents in which very important political and economic processes and strategic changes are taking place that affect all Mediterranean countries, but also the whole world. Therefore, it is of special importance to understand the significance of these processes and changes in the multipolar world created in the wider region of the Mediterranean. 


\section{REFERENCES}

Adamczyk, Marcin, and Rutkowska, Patrycja. 2018. "China on the road to becoming a sea power - is this the renaissance of AT Mahan's and JS Corbett's theory?" Kultura - Historia - Globalizacja 23: 1-16.

Adamo, Katia, and Paolo, Garonna. 2009. "Euro-Mediterranean Integration and Cooperation: Prospects and Challenges." UNECE Annual Report Economic Essays 20099 UNECE. https://www.unece.org/fileadmin/DAM/oes/ nutshell/2009/9_EuroMediterranean.pdf.

Arase, David. 2015. China's Two Silk Roads: Implications for Southeast Asia (Amended Version).

Behr, Timo, Erik Brattberg, Jyrki Kallio, Mika Aaltola, Charly Salonius-Pasternak, Andreas Raspotnik, Maija Salonen. 2013. "Study The maritime dimension of CSDP: Geostrategic maritime challenges and their implications for the European Union.” Directorate-General For External Policies Of The Union, Policy Department.

Benoit, Guillaume, and Comeau, Aline. 2005. A Sustainable Future for the Mediterranean: The Blue Plan's Environment and Development Outlook. London: Earthscan.

Black, Bruce J. 2006. The Legacy of Mahan for the 21st Century. United States: Army War College Carlisle Barracks PA.

Blomdahl, Mikael. 2019. "Changing the Conversation in Washington? An Illustrative Case Study of President Trump's Air Strikes on Syria, 2017." Diplomacy \& Statecraft 30 (3): 536-55. doi: 10.1080/09592296. 2019.1641924.

Božić, Nemanja. 1974. Posleratna globalna strategija SAD. Beograd: Institut za međunarodnu politiku i privredu.

Braudel, Fernand. 1972. The Mediterranean and the Mediterranean World in the Age of Philip II, Volume 1. Collins.

Brodel, Fernan. 2007. Sredozemlje u Starom veku: praistorija i anticko doba. Novi Sad: Akademska knjiga.

Calleya, Stephen. 2019. What prospects for transatlantic relations and the Mediterranean?

Casarini, Nicola. 2015. "Is Europe to benefit from China's Belt and Road initiative." Istituto Affari Internazionali 15 (40): 1-11.

Celac, Sergiu, Alessandra Giada Dibenedetto, Alexandru Purcăru $\square$, Izel Selim. 2019. Militarization of the Black Sea and Eastern Mediterranean theatres: A new challenge to NATO. New Strategy Center \& Centro Studi Internazionali, Policy Paper 
Chang, Yen-Chiang. 2018. “The '21st Century Maritime Silk Road Initiative' and naval diplomacy in China." Ocean and Coastal Management 153 (2018): 148-156. doi: 10.1016/j.ocecoaman.2017.12.015.

Chaziza, Mordechai. 2018. "The Chinese Maritime Silk Road Initiative." Mediterranean Quarterly 29 (2): 54-69. doi: 10.1215/10474552-6898099.

Cheng, Dean. 2011. "Sea Power and the Chinese State: China's Maritime Ambitions.” Backgrounder (2576): 1-12. http:/ / report.heritage.org/bg2576.

Ciro, Elliot Zoppo. 1982. "The Mediterranean In American Foreign Policy.", Revista de Estudios Internacionales 3 (1): 69-101. http://www.cepc.gob.es/ Publicaciones / revistas / fondo-historico?IDR=14\&IDN=1206\&IDA $=35031$.

Connolly, Richard. 2017. „Towards a Dual Fleet? The Maritime Doctrine of the Russian Federation and the Modernisation of Russian Naval Capabilities", Research Paper 02. Rome: NATO Defense College. http://www.ndc.nato.int/ news/news.php?icode $=1061 \#$, last assesed 24 June 2019.

Cvrtila, Vlatko. 2004. Hrvatska i NATO. Zagreb: CPI.

Diaconu, Florin. 2008. "A Renewed Geopolitical And Geostrategic Role For The Mediterranean Sea." Strategic Impact 3: 43-46.

Dillery, C. E. 2006. 'US Interests in the Mediterranean.” Mediterranean Quarterly 17 (2): 7-16. doi: 10.1215/10474552-2006-002.

Duchâtel, Mathieu, and Alexandre Sheldon Duplaix. 2018. "Blue China: Navigating the Maritime Silk Road to Europe.” ECFR.EU. April 23, 2018. https://www.ecfr.eu/publications/summary/blue_china_navigating_the_ma ritime_silk_road_to_europe, last assesed 2 August 2019.

Đorđević, Branislav, and Lađevac, Ivona. 2016. „Benefits and limitations of „One Belt One Road Strategy" in relations between China and the European Union -Serbian perspective". The Review of International Affairs. 67 (1162-1163): 57-69

Ekman, Alice. 2018. China in the Mediterranean: An Emerging Presence. Paris: IfriCenter for Asian studies. Notes de l'Ifri.

Foggo, James III. 2019. Center for Strategic \& International Studies [CSIS]. „Geostrategic Flashpoint: The Eastern Mediterranean: Shifting Alliances, Diverging Interests, and New Actors.“ February 11, 2019, Washington, D.C. https://www.csis.org/events/geostrategic-flashpoint-eastern-mediterranean, last assesed 9 September 2019.

Frankenthal, Kira. 2019. The EU as a Maritime Security Actor in the Mediterranean Sea (Vol. 2). Nomos Verlag. 
Germond, Basil, and Grove, Eric. 2010. Maritime security in the Mediterranean: European and transatlantic approaches. Working Paper. Washington: The German Marshall Fund of the United States, Roma: The Istituto Affari Internazionali. Greenwood, Ted. 1993. US and NATO Force Structure and Military Operations in the Mediterranean. Washington DC: National Defense University.

International Ogranization for Migration [IOM]. "Mediterranean Migrant Arrivals Reach 60,309 in 2018; Deaths Reach 1,524." http://www.iom.int/ news/mediterranean-migrant-arrivals-reach-60309-2018-deaths-reach-1524, last assessed 14 August 2018.

International Organization for Migration [IOM]. 2017. Fatal Journeys, Improving Data on Missing Migrants 3 (2). Geneva.

Jérôme, Henry. 2016. China's Military Deployments in the Gulf of Aden: Anti-piracy and Beyond. IFRI Center for Asian Studies.

Jingping, Xi. 2017. The Governance of China. Beijing: Foreign Languages Press.

Khader, Bichara and Amirah-Fernández, Haizam. 2020. Thirty years of EUMediterranean Policies (1989-2019): an assessment, Working Paper 8/2020. Elcano Royal Institute.

Kissinger, Henry. 2002. Does America need a foreign policy?: Toward a diplomacy for the 21st century. Simon and Schuster.

Lesser, Ian O. 1998. „The changing Mediterranean security environment: a transatlantic perspective." The Journal of North African Studies 3 (2): 212-228, doi: 10.1080/13629389808718330.

Lesser, Ian O. 2015. "The United States and the Future of Mediterranean Security: Reflections from GMF's Mediterranean Strategy Group." Mediterranean Policy Program, Washington: Policy Brief.

Li, Nan. 2009. "The Evolution of China's Naval Strategy and Capabilities: From "Near Coast" and "Near Seas" to "Far Seas"." Asian Security 5 (2): 144-169. doi: $10.1080 / 14799850902886567$.

Litsas, Spyridon N. 2016. "Russia in the Eastern Mediterranean: Intervention, Deterrence, Containment." Digest of Middle East Studies 26 (1): 56-73. doi: 10.1111/dome.12103.

Litsas, Spyridon N. 2019. "The Russian Foreign Policy in the Eastern Mediterranean: A Sui-generis Revisionism." In The New Eastern Mediterranean: Theory, Politics and States in a Volatile Era, eds. Spyridon Litsas, and Aristotle Tziampiris, 169-190. Springer, Cham.

Luttwak, Edward N. 1974. The Political Uses of Sea Power. Baltimore: Johns Hopkins University Press. 
Mahan, Alferd T. 2007. Influence of Sea Power upon History, 1660-1783. Cosimo Classics, New York (Original edition: Boston: Little, Brown, and Company, 1890.).

Manfred, Hafner, Tagliapietra Simone, and El Elandaloussi El Habib. 2012. "Outlook for Oil and Gas in Southern and Eastern Mediterranean Countries". MEDPRO Technical Report 18.

Marjanović, Radomir. 1983. Opšta vojna geografija sa europskim ratistem. Beograd: VIZ.

Martinez, Miguel, Hannah Murdock, and Floriane Schaeffer. 2013. "Geopolitics of Gas in the Mediterranean." Eurogroup Consulting/Sciences Po.

Mays, Michael C. 2013. NATO: Identifying New Trends within an Old Relationship. United States: Army Command and General Staff College Fort Leavenworth KS School of Advanced Military Studies.

Müller-Markus, Christina. 2016. "China moors in the Mediterranean: a sea of opportunities for Europe?” Notes Internacionals 156: 1-4. CIDOB: Barcelona Centre for International Affairs.

Naj, Džozef S. 2012. Buduínost moći. Beograd: Arhipelag.

Parker, Ronald D. 2003. Mahan for the Twenty First Century: His Principles Still Apply to National Power. United States: Marine Corps Command And Staff College Quantico VA.

Pavić, Radovan. 1971a. Uvod u opín političku geografiju i geopolitiku (sa osnovama geostrategije). Zagreb: Sveučilište u Zagrebu, FPN Zagreb.

Pavić, Radovan. 1971b. "Neke geopolitičke i geostrateške značajke svjetskog mora i sredozemnog bazena." Politickea misao 8 (4): 385-407.

Pierini, Marc. 2017. „,The European Union and the Mediterranean Area: Dealing with Conflicts, Tensions and Resets." IE Med. Mediterranean Yearbook. Med. 2017

Pleitgen, Frederik. 2019. "In the Mediterranean, US aircraft carrier operations serve as floating American diplomacy." CNN, April 23, 2019. https://edition. cnn.com/2019/04/23/europe/us-carrier-operations-mediterraneansea/index.html, last assessed 22 October 2019.

Putten, Frans Paul Van Der. 2016. "Infrastructure and Geopolitics: China's Emerging Presence in the Eastern Mediterranean." Journal of Balkan and Near Eastern Studies 18 (4): 337-51. doi: 10.1080/19448953.2016.1195978.

Radojević, Slobodan. 2012. "Slučaj somalijskih pirata." Vojno delo 64 (1): 68-88. https:/ / scindeks.ceon.rs/article.aspx?artid=0042-84261201068R.

Radojević, Slobodan. 2017a. "NATO u Sredozemlju na početku 21. veka: pomorske snage u usponu?" Medunarodni problemi 69 (1): 50-77. doi: 10.2298/MEDJP1701050R. 
Radojević, Slobodan. 2017b. „Uloga pomorskih i vazduhoplovnih snaga NATO u Sredozemlju posle Hladnog rata." Doktorska disertacija, Univerzitet u Beogradu: Fakultet političkih nauka.

Radojević, Slobodan. 2018. "Odnos politike i strategije: reafirmacija strategijskih studija?” Srpska politickea misao 62 (4): 77-94. doi: 10.22182/spm.6242018.4.

Rowlands, Kevin. 2012. “ 'DECIDED PREPONDERANCE AT SEA' Naval Diplomacy in Strategic Thought." Naval War College Review 65 (4): 89-105.

Rubin, Aviad, and Ehud Eiran. 2019. "Regional Maritime Security in the Eastern Mediterranean: Expectations and Reality." International Affairs 95 (5): 979-997. doi: 10.1093/ia/iiz146.

Silva, Daniel Rocha. 2015. "The role of sea power in China s rise: is maritime conflict inevitable?.” Análise Social 217: 708-732.

Skordeli, Marina. 2015. "New Horizons in Greek-Chinese Relations: Prospects for the Eastern Mediterranean." Mediterranean Quarterly 26 (1): 59-76. doi: 10.1215/10474552-2872977.

Srivastava, Nitika. 2016. "Russias Naval Resurgence in Eurasia?" Maritime Affairs: Journal of the National Maritime Foundation of India 12 (2): 42-57. doi: 10.1080/09733159.2016.1232952.

Steinhilper, Elias, and Rob Gruijters. 2018. "A Contested Crisis: Policy Narratives and Empirical Evidence on Border Deaths in the Mediterranean." Sociology 52 (3): 515-533. doi: 10.31235/osf.io/dn7a5.

Stepić, Milomir. 2019. „Geopolitika: od geografske i politikološke discipline do samostalne nauke." Srpska politickea misao 63 (1): 75-96. doi: 10.22182/spm.6312019.4.

Stergiou, Andreas. 2012. „Russian policy in the eastern Mediterranean and the implications for EU external action.", European Union Institute for Security Studies, (EUISS), 25 July 2012, https://www.iss.europa.eu/content/russian-policyeastern-mediterranean-and-implications-eu-external-action, last assesed 13 November 2019.

Tazzioli, Martina. 2015. „The politics of counting and the scene of rescue.” Radical Philosophy: philosophical journal of the independent left 192 (1-6): 2-6.

Thornton, Rod. 2018. "The Russian Military Commitment in Syria and the Eastern Mediterranean.” The RUSI Journal 163 (4): 30-38. doi: 10.1080/03071847.2018.1529892.

Thornton, Rod. 2019. "Countering Prompt Global Strike: The Russian Military Presence in Syria and the Eastern Mediterranean and Its Strategic Deterrence Role." The Journal of Slavic Military Studies 32 (1): 1-24. doi: 10.1080/13518046.2019.1552655. 
United Nations Conference On Trade And Developmenton [UNCTAD]. 2018. Review Of Maritime Transport 2018. New York and Geneva.

Vamvakas, Petros. 2014. "Global Stability and the Geopolitical Vortex of the Eastern Mediterranean." Mediterranean Quarterly 25 (4): 124-40. doi: 10.1215/10474552-2830902.

Vukadinović Cehulic, Lidija. 2010. Euroatlantizam i Suvremeni Medunarodni Odnosi. Podgorica: CID, Zagreb: Politička kultura.

Vukadinović, Radovan. 1986. Mediteran į̧među rata i mira. Zagreb: Školska knjiga.

Vuković, Nebojša. 2017. "Sredozemlje kao geostrategijsko čvorište globalnog značaja." U Svet i nove geopolitičke paradigme, (prir.) Milomir Stepić, 269-292. Beograd: Institut za političke studije.

Weissenbacher, Manfred. 2012. "Energy Security in the Euro-Mediterranean Region", in Change and Opportunities in the Emerging Mediterranean, Stephen Calleya and Monika Wohlfeld (eds.), 452-469. Malta, Gutenberg Press.

Widén, Jerker J. 2011. "Naval Diplomacy - A Theoretical Approach.” Diplomacy \& Statecraft 22 (4): 715-33. doi: 10.1080/09592296.2011.625830.

Zakić, Katarina, and Bojan Radišić. 2019. "China's Belt And Road Investment Projects In The Balkan Countries: Six Years After." The Review of International Affairs 70 (1175): 48-68.

Zulfqar, Saman. 2018. "Competing Interests of Major Powers in the Middle East: The Case Study of Syria and Its Implications for Regional Stability." Perceptions XXIII (1): 121-147.

Živojinović, Dragoljub R. 1980. "Istorijski koreni borbe velikih sila za prevlast u Sredozemlju i bezbednost SFRJ.” U Sredozemlje i bez̧bednost SFRJ - završna studija, Beograd: Centar za strategijska istraživanja GŠ JNA.

Горшков, Сергей Георгиевич. 1979. Морская мощь государства, 2-е издание, дополненное. Москва: Воениздат.

Морская Аоктрина Российской Федерации, утв. Президентом РФ, 26.07.2015. Совет Безопасности Российской Федерации. http:// www.scrf.gov.ru/security/military/document34/, poslednji pristup 11. jula 2019.

Рискин, Андрей. 2019. „США доставили в Средиземное море 200 тысяч тонн „межАународной Аипломатии““." Независимая газета. http:/ /www.ng.ru/columnist/2019-04-24/100_kolonka240419.html, poslednji pristup 22. oktobra 2019. 


\section{POLITIČKE I STRATEGIJSKE PROMENE U SREDOZEMLJU}

Apstrakt: U radu se polazi od geostrategijskog značaja Sredozemlja i Sredozemnog mora u prošlosti što predstavlja svojevrstan uvod u razmatranje sadašnjih i budućih događaja u ovom makroregionu. Autor najpre kroz istorijsku i prostornu perspektivu razmatra ispoljavanje moći, uticaja i interesa velikih sila u Sredozemlju. U radu se kroz teoriju i praksu upotrebe ratnih mornarica velikih sila posmatraju političke i ekonomske promene u Sredozemlju. Autor ukazuje da će se geopolitički i geostrategijski značaj Sredozemlja dodatno povećati u budućnosti, kao rezultat stalnih regionalnih i globalnih težnji da se politička i ekonomska dinamika ovog regiona poveća. Sve izraženija rastuća konkurencija između SAD i Kine imaće direktan uticaj na Sredozemlje. Autor zaključuje da će Sredozemlje ostati "poligon" za nadmetanje SAD, Kine i Rusije i region u kome se najočiglednije mogu sagledati politički i ekonomski procesi i strategijske promene u svetu.

Kjučne reči: Sredozemlje, Sredozemno more, strategijske promene, politički i ekonomski procesi, SAD, Kina, Rusija.

Received: $15 / 6 / 2020$

Accepted: $13 / 8 / 2020$ 